JEMAP : Jurnal Ekonomi, Manajemen, Akuntansi dan Perpajakan

ISSN : $\quad$ | Vol.1 | No.1 | April 2018

\title{
Pengaruh Faktor-Faktor Keuangan Dan Perilaku Herding Investor Terhadap Underpricing Pada Penawaran Perdana Saham Perusahaan Yang Terdaftar Di Bei
}

\author{
Alviano Renoldy Saputra dan Elizabeth Lucky Maretha Sitinjak \\ email: lucky@unika.ac.id \\ Program Studi Akuntansi, Fakultas Ekonomi dan Bisnis \\ Universitas Katolik Soegijapranata
}

\begin{abstract}
The purpose of this study is to examine the influence of financial factors (firm liquidity ratio, and non-financial factors (herding behavior) influence on underpricing. There are 73.21 percent of companies experiencing underpricing during the public offering in 2009-2013.Therefore researchers will see the influence financial factors and herding behavior to the underpricing phenomenon. Underpricing is projected as an abnormal return, the liquidity is proxies by the current ratio (CR), the firm's activity is proxies by total assets of turnover ratio (TATO), profitability is projected Return on Assets (ROA), Assets (ROA), leverage is proxies debt to equity ratio (DER). This study uses multiple regression and fulfills all the classical assumptions. The results showed company liquidity, profitability, and herding behavior significantly influence underpricing.
\end{abstract}

Keywords: Underpricing, CR, TATO, ROA, DER, Herding Behavior

\section{PENDAHULUAN}

Sumber pendanaan yang perusahaan butuhkan, dapat bersasal dari dalam maupun luar perusahaan. Proses go public adalah salah satu alternatif yang biasanya digunakan oleh perusahaan guna memperoleh pendanaan dari luar perusahaan, dengan cara menjual sebagian saham yang dimiliki perusahaan kepada publik. Penawaran saham perdana ini lebih sering disebut dengan Initial Public Offering (IPO).Pada prosesnya, perusahaan akan menunjuk seorang underwriter untuk memproses kegiatan penjualan saham perdananya dan sering kali underwiter akan menerima risiko yang ditimbulkan jika saham tersebut tidak laku dijual. Perusahaan akan menerima dana IPO sebesar jumlah lembar yang ditawarkan dikali dengan harga per saham yang ditawarkan. Masalah yang sering timbul adalah seringkali perusahaan akan menentukan harga sahamnya dengan 
JEMAP : Jurnal Ekonomi, Manajemen, Akuntansi dan Perpajakan

harga tinggi agar dana yang didapat oleh perusahan semakin besar, namun underwriter justru berperilaku sebaliknya. Underwiter akan menilai saham perusahaan tersebut lebih rendah agar risiko yang ditimbulkan jika saham tersebut tidak laku dijual akan lebih kecil. Hal inilah yang sering disebut sebagai fenomena underpricing, dimana harga saham dinilai lebih kecil dari harga pasar.

Penelitian yang dilakukan Halim (2005) dengan judul penelitian tentang Pengaruh Likuiditas, Leverage dan Dividen terhadap Tingkat Underpricing Pada Industri Manufaktur di Bursa Efek Jakarta. Hal ini sejalan dengan penelitian Paramita (2001) dan Yuliana (2013). Hasil berbeda ditemukan oleh Dewi (2007) dan Junaeni (2013) bahwa tingkat likuiditas perusahaan tidak berpengaruh terhadap tingkat underpricing. Paramita (2007) melakukan penelitian terhadap Kinerja Keuangan Perusahaan Publik Melalui Pengamatan Kepada Perusahaan Manufaktur yang Terdaftar di Bursa Efek Jakarta Tahun 2004, 2005, 2006 terhadap tingkat underpricing saham menunjukan variabel ROE, DER, PER, CR, dan TATO secara bersama-sama mempunyai pengaruh terhadap tingkat underpricing terbukti diterima, yang artinya perubahan nilai variabel ROE, DER, PER, CR, dan TATO akan mempengaruhi tingkat underpricing. Hal ini sejalan dengan penelitian yang ditemukan oleh Paramita (2007). Hasil berbeda ditemukan oleh Permana (2011) dan Surya (2013) yang menyatakan tingkat aktivitas perusahaan tidak berpengaruh terhadap tingkat underpricing. Return On Asset (ROA) menunjukan seberapa jauh perusahaan yang dapat dipergunakan secara efektif untuk mengasilkan laba. Jika Return On Asset (ROA) tinggi, maka perusahaan akan mendapatkan keuntungan, sehingga harga saham akan naik (Dharmastuti, 2004). Hal ini sejalan dengan penelitian yang dilakukan oleh Wiryawan (2002). Hal berbeda ditemukan oleh Retnowati (2013) dan Dominique (2013), Return On Asset (ROA) tidak berpengaruh signifikan terhadap tingkat underpricing.

Dharmastuti (2004) dalam penelitiaannya menemukan bahwa Debt to Equity Ratio (DER) berpengaruh signifikan terhadap tingkat underpricing. Hasil berbeda yang ditemukan Retnowati (2013) dan Dominique (2013) justru 
JEMAP : Jurnal Ekonomi, Manajemen, Akuntansi dan Perpajakan

menemukan hal yang berbeda, yaitu rasio Debt to Equity Ratio (DER) tidak berpengaruh signifikan terhadap tingkat underpricing. Berdasarkan penelitian yang dilakukan oleh Kristiantari (2012) meneliti Tujuan penggunaan dana hasil IPO untuk investasi berpengaruh signifikan negatif terhadap tingkat underpricing karena pendiri perusahaan yang memutuskan go public cenderung mendiversifikasi risikonya dan kecenderungan saham yang dijual kepublik mengalami fenomena underpricing. Hal ini sejalan dengan penelitian yang dilakukan oleh Aini (2013), hasil berbeda ditemukan oleh Ismiyati et al (2010) motif go public tidak berpengaruh terhadap tingkat underpricing saham saat melakukan IPO.Rufnialfian (2009) melakukan penelitian terhadap perusahaan yang IPO di BEJ dimana reputasi underwriter tidak berpengaruh terhadap underpricing. Hal ini sejalan dengan penelitian yang dilakukan Trisnawati (1999) dimana reputasi underwriter tidak berpengaruh terhadap intial return. Chastista et al (2005) melakukan penelitian di BEJ dari tahun 1994 - 2001 dimana reputasi underwriter berpengaruh signifikan terhadap underpricing. Hal ini sejalan dengan penelitian yang dilakukan oleh Andina (2011) dan Irawati (2009).

Dominique et al (2013) yang meneliti tingkat underpricing pada perusahaan go public di Bursa Efek Indonesia pada tahun 2005 - 2009 menemukan adanya hubungan positif antara reputasi auditor dan tingkat underpricing. Penelitian ini didukung juga oleh penelitian yang dilakukan oleh Paramita (2009) dan Kristiantari (2012). Hal tidak ini sejalan dengan penelitian yang dilakukan oleh Yasa (2002) dan Aini (2013) menyebutkan bahwa reputasi auditor tidak berpengaruh signifikan terhadap underwriter. Penelitian ini memasukan variabel Herding yang dijelaskan sebagai sebagai perilaku yang terjadi karena adanya suatu interakasi antara dua individu atau lebih (Ismiyati et al, 2010). Penelitian yang dilakukan oleh Caparrelli et al (2009) yang berjudul Herding in the Italian Stok market: A Case of Behavioral Finance menyatakan bahwa terdapat hubungan signifikan antara underpricing saham dan perilaku herding. Penelitian ini didukung oleh Gleason et al (2003) dan Caparrelli et al (2004) yang menyatakan fenomena herding berpengaruh pada tingkat underpricing. Hasil berbeda ditemukan oleh Ismiyati et al (2010) dan Gunawan 
JEMAP : Jurnal Ekonomi, Manajemen, Akuntansi dan Perpajakan

ISSN :

| Vol. 1 | No. 1 | April 2018

(2011) bahwa tidak ada hubungan yang signifikan antara herding dan underpricing.

Data yang peneliti dapatkan, selama tahun 2009 - 2013 ada 112 perusahaan yang melakukan IPO, pada tahun 2009 terdapat 12 perusahaan yang melakukan IPO, delapan diantarannya mengalami fenomena underpricing atau sekitar 66,66 persen. Tahun 2010 dari 22 perusahaan yang melakukan IPO atau sekitar 86,36 persen perusahaan mengalami fenomena underpricing meningkat dari tahun 2010. Tahun 2011, 2012 dan 2013 fenomena underpricing tetap masih terjadi pada perusahaan yang melakukan IPO, tahun 2010 dari 25 perusahaan yang melakukan IPO, 16 diantaranya mengalami fenomena underpricing atau sekitar 64 persen, tahun 2012 fenomena underpricing meningkat menjadi 90,90 persen atau dari 22 perusahaan yang melakukan IPO, 20 dianataranya mengalami fenomena underpricing dan ditahun 2013 sebanyak 20 perusahaan uang mengalami fenomena underpricing atau 64,51 persen dari 31 perusahaan yang melakukan IPO.

\section{LANDASAN TEORI}

Underpricing. Underpricing merupakan fenomena yang terjadi ketika harga saham pada saat penawaran lebih rendah daripada harga yang terbentuk ketika saham pertama kali diperdagangkan pada pasar sekunder. Beberapa penelitian dari para ahli mengenai underpricing. Bodie et al 2003: 67 dalam Kristiantari (2012) mengatakan underpricing adalah adanya kenaikan harga pada saat saham diperdagangkan di bursa atau pasar sekunder pada saat IPO. Menurut Husnan (2003: 274) abnormal return adalah selisih antara tingkat keuntungan sebenarnya dengan tingkat keuntungan yang diharapkan.Melalui pasar sekunder para investor berusaha untuk mendapatkan tingkat keuntungan yang lebih besar dari tingkat keuntungan yang diharapkan dengan terlebih dahulu mempertimbangkan faktor risiko yang mungkin muncul atas alternatif investasi yang dipilih. 
JEMAP : Jurnal Ekonomi, Manajemen, Akuntansi dan Perpajakan

Rencana Penggunaan Dana (RPD). Salah satu informasi yang terdapat dalam prospektus adalah informasi mengenai rencana atau tujuan penggunaan dana IPO. Rencana penggunaan dana yang diperoleh dari penawaran umum diberikan secara presentasi dari kegiatan-kegiatan yang akan dilakukan. Tujuan penggunaan dana dari hasil go public pada umumnya digunakan untuk (1) Ekspansi, Peningkatan aktivitas ekonomi dan pertumbuhan dunia usaha menyebabkan membesar dan meluasnya usaha yang ditandai dengan penciptaan pasar baru, perluasan fasilitas, perekrutkan pegawai. (2) Memperbaiki struktur permodalan struktur modal adalah proposi dalam menentukan pemenuhan kebutuhan belanja perusahaan dengan sumber pendanaan jangka panjang yang berasal dari dana internal dan dana eksternal, dengan demikian struktur modal adalah struktur keuangan dikurangi utang jangka pendek. Untuk melakukan pengalihan pemegang saham (divestasi). Divestasi adalah pengurangan beberapa jenis aset baik dalam bentuk finansial atau barang, dapat pula disebut penjualan dari bisnis yang dimiliki oleh perusahaan.

Reputasi Underwriter. Underwriter merupakan lembaga yang mempunyai peran kunci pada setiap emisi efek di pasar modal. Dalam melaksanakan fungsinya underwriter membantu emiten dalam rangka mempersiapkan pernyataan pendaftaran emisi beserta dokumen pendukungnya, memberi masukan di bidang keuangan seperti jumlah dan jenis efek apa yang akan diterbitkan, bursa yang dipilih untuk mencatatkan saham, penentuan jadwal emisi, penunjukkan lembaga penunjang lain, melakukan penjaminan efek yang diemisikan dan lain sebagainya. Dalam proses go public, sebelum saham diperdagangkan di pasar sekunder (bursa efek), terlebih dahulu saham perusahaan yang akan go public dijual dipasar perdana.

Herding. Herding dijelaskan sebagai investor atau sekumpulan investor cenderung berperilaku mengikuti investor lain. Sebagai contoh yang terjadi pada pasar modal, terkadang kita dibingungkan untuk memilih manakah yang terbaik dari dua alternatif investasi dalam sekuritas. Pilihan ini tidak akan menjadi masalah ketika kita mengetahui dengan tepat potensi yang dimiliki masing- 
JEMAP : Jurnal Ekonomi, Manajemen, Akuntansi dan Perpajakan

masing saham tersebut, tetapi apa yang terjadi jika dua saham ini belum kita kenal dengan baik.Para ahli mendefinisikan herding dipasar modal sebagai berikut. Menurut Brunnermeier (2001: 147) perilaku herding dijelaskan dengan orangorang yang dengan cara buta (blindly) mengikuti keputusan orang lain. Lakonishok et al., (1992) mendefinisikan herding pada pasar modal sebagai kecenderungan dari sekelompok money managers untuk membeli (menjual) khususnya saham pada saat yang bersamaan, relatif terhadapapa yang dapat diharapkan jika money managers tersebut berdagang sendiri. Herding terkait dengan korelasi antara pola trading dari sekelompok traders dan kecenderungan untuk membeli dan menjual sekumpulan saham yang sama tanpa mempertimbangkan faktor fundamental maupun sektoral yang terjadi. Perilaku herding ini sudah banyak ditemui dibeberapa pasar modal dunia, termasuk Indonesia. Perilaku herding lebih terlihat saat kondisi pasar sedang krisis (stress market) dikarenakan investor tidak telalu memahami kondisi pasar yang terjadi, sehingga perilaku yang ditimbulkan adalah meniru investor lain (Gunawan, 2013).

Pengembangan Hipotesis. Rasio Likuiditas yang diproxikan dengan CR (Current Ratio) mempunyai informasi penting bagi investor dalam membuat keputusan investasi. Rasio Likuiditas memberikan informasi kepada investor mengenai efektivitas operasional perusahaan. Likuiditas yang tinggi akan mengurangi ketidakpastian perusahaan di masa yang akan datang, karena likuiditas yang tinggi akan berdampak pada kinerja perusahaan dimasa depan. Sehingga dapat dijelaskan bahwa semakin tinggi tingkat likuiditas perusahaan, maka operasional perusahaan dapat dikatakan baik. Oleh karena itu, dapat dijelakan bahwa rasio likuiditas berpengaruh negatif terhadap underpricing. Hal ini juga dijelaskan oleh peneliti-peneliti sebelumnya. Hipotesis yang dibentuk:

\section{$\mathrm{H}_{1}$ : Rasio likuiditas berpengaruh negatif terhadap Underpricing pada Perusahaan yang Melakukan IPO di Bursa Efek Indonesia Periode 2007 - 2013. \\ Rasio Aktivitas yang diproxikan dengan TATO (Total Asset Turnover)} mempunyai informasi penting bagi investor dalam membuat keputusan investasi. Rasio aktivitas memberikan informasi kepada investor mengenai efektivitas 
JEMAP : Jurnal Ekonomi, Manajemen, Akuntansi dan Perpajakan

operasional perusahaan. Tingkat aktivitas perusahaan yang tinggi akan mengurangi ketidakpastian perusahaan di masa yang akan datang. Ketidakpastian yang dimaksud adalah komposisi penjualan dengan total aset belum bisa menjelaskan kondisi perusahaan dimasa depan. Jika perputaran aset perusahaan baik (tinggi), maka tingkat efisiensi terhadap penggunaan aset perusahaan juga baik. Oleh karena itu, bisa dijelaskan bahwa rasio aktivitas berpengaruh negatif terhadap underpricing. Hal ini juga dijelaskan oleh peneliti sebelumnya,Paramitha (2007) meneliti tentang analisis kinerja keuangan perusahaan publik melalui pengamatan terhadap perubahan harga dan return saham. Sampel penelitian ini adalah perusahaan manufaktur yang terdaftar di Bursa Efek Jakarta tahun 20042006. Teknik analisis data menggunakan uji asumsi klasik, analisis linear berganda. Hasil penelitian tersebut menunjukan variabel ROE, DER, PER, CR dan TOTA berpengaruh signifikan negatif terhadap return saham. Hipotesis yang diajukan berdasarkan penjelasan di atas adalah sebagai berikut:

\section{$\mathrm{H}_{2}$ : Rasio aktivitas berpengaruh negatif terhadap Underpricing pada Perusahaan yang melakukan IPO di Bursa Efek Indonesia Periode $2007-2013$ \\ Rasio Profitabilitas yang diproxikan dengan ROA (Return On Assest)} mempunyai informasi penting bagi investor dalam membuat keputusan investasi. Profitabilitas perusahaan memberikan informasi kepada investor mengenai efektivitas operasional perusahaan. Profitabilitas yang tinggi akan mengurangi ketidakpastian perusahaan di masa yang akan datang. Profitabilitas perusahaan yang tinggi menandakan perusahaan tersebut dalam kondisi profit (laba), diharapkan dengan profitabilitas yang tinggi maka investor akan mendapatkan sebagian keuntungan perusahaan dalam bentuk deviden. Sehingga ketidakpastian perusahaan dimasa depan tersebut dapat diukur dengan rasio profitabilitas. Oleh karena itu, bisa dijelakan bahwa rasio profitabilitas berpengaruh negatif terhadap underpricing. Hal ini juga dijelaskan oleh peneliti sebelumnya, Yasa (2001) meneliti tentang penyebab underpricing pada penawaran saham perdana di bursa efek jakarta. Sampel yang Yasa (2001) digunakan adalah perusahaan yang melakukan IPO dari tahun 1990-2001. Teknik analisis data menggunakan uji 
JEMAP : Jurnal Ekonomi, Manajemen, Akuntansi dan Perpajakan

asumsi klasik, analisis linear berganda. Hasilnya adalah ROA berpengaruh signifikan terhadap underpricing. Hipotesis yang diajukan berdasarkan penjelasan di atas sebagai berikut:

\section{$\mathrm{H}_{3}$ : Rasio profitabilitas berpengaruh negatif terhadap Underpricing Perusahaan yang Melakukan IPO di Bursa Efek Indonesia Periode $2007-2013$}

Rasio Leverege yang diproxikan dengan DER (Debt to Equity Ratio) menunjukkan kemampuan perusahaan dalam membayar hutangnya dengan equity yang dimilikinya. Tingkat leverage yang tinggi menunjukkan risiko suatu perusahaan juga tinggi. Hal ini akan menimbulkan ketidakpastian harga saham perdana yang besar pula, yang pada akhirnya akan mempengaruhi underpricing. Oleh karena itu, bisa dijelakan bahwa rasio leverege berpengaruh positif terhadap underpricing. Hal ini juga dijelaskan oleh peneliti sebelumnya, Paramitha (2007) meneliti tentang analisis kinerja keuangan perusahaan publik melalui pengamatan terhadap perubahan harga dan return saham. Sampel penelitian ini adalah perusahaan manufaktur yang terdaftar di Bursa Efek Jakarta tahun 2004-2006. Teknik analisis data menggunakan uji asumsi klasik, analisis linear berganda. Hasil penelitian tersebut menunjukan variabel ROE, DER, PER, CR dan TOTA berpengaruh signifikan positif terhadap return saham. Hipotesis yang diajukan:

\section{$\mathrm{H}_{4}$ : Rasio leverage berpengaruh positif terhadap Underpricing Perusahaan yang Melakukan IPO di Bursa Efek Indonesia Periode 2007-2013}

Rencana Penggunaan Dana (RPD) merupakan variabel dummy yang dihitung dengan memberikan skore 1 jika perusahan menggunakan dana IPO untuk keperluan investasi atau pembelian aset dan akan memberikan skore 0 jika perusahaan menggunakan dana IPO tidak untuk keperluan investasi atau pembelian aset. Tujuan penggunaan dana hasil IPO yang dapat diidentifikasi dari data prospektus yaitu untuk kebutuhan investasi atau ekspansi dan untuk perbaikan struktur modal. Bagi perusahaan dengan kualitas baik, penggunaan dana IPO untuk belanja modal dapat dianggap sebagai upaya meningkatkan kualitas perusahaan melalui peningkatan kapasitas produksi, sementara bagi 
JEMAP : Jurnal Ekonomi, Manajemen, Akuntansi dan Perpajakan

perusahaan dengan kualitas jelek hal itu tidak bermakna apa. Jika dana IPO digunakan untuk keperluan investasi, investor dapat menganggap bahwa kualitas perusahaan adalah baik, sehingga tingkat underpricing seharusnya rendah. Oleh karena itu, bisa dijelakan Rencana Penggunaan Dana IPO berpengaruh negatif terhadap underpricing. Hal ini juga dijelaskan oleh peneliti sebelumnya, antara lain: Kristiantari (2012) dalam penelitian yang berjudul analisis faktor-faktor yang mempengaruhi undepricing saham pada penawaran saham perdana di Bursa Efek Indonesia. Sampel yang digunakan adalah seluruh perusahaan yang melakukan IPO di BEI pada periode 1997 - 2010. Metode yang digunakan adalah uji parsial. Hasilnya adalah tujuan penggunaan dana berpengaruh signifikan negaitf pada underpricing. Hipotesis yang diajukan sebagai berikut:

\section{H5: Rencana Penggunaan Dana (RPD) berpengaruh negatif terhadap Underpricing Saham pada Bursa Efek Indonesia yang melakukan IPO periode $2007-2013$}

Reputasi Underwriter (UND) merupakan variabel dummy yang dihitung dengan memberikan skore 1 jika perusahan menggunakan jasa underwriter yang memiliki rangking 10 besar berdasarkan frequency $(\mathrm{X})$ yang diperoleh pada fact book yang dikeluarkan oleh BEI setiap tahun. Reputasi Underwriter dikatakan baik jika underwriter tersebut aktif dalam melakukan jual beli saham. Skore 1 jika underwriter tersebut masuk dalam jajaran 10 besar underwriter teraktif, dan skore 0 jika underwriter berada diluar jajaran 10 besar underwriter teraktif. Underwriter dengan reputasi tinggi lebih mempunyai kepercayaan diri terhadap kesuksesan penawaran saham yang diserap oleh pasar. Dengan demikian ada kecenderungan underwriter yang bereputasi tinggi lebih berani memberikan harga yang tinggi sebagai konsekuensi dari kualitas penjaminannya, sehingga tingkat underpricing pun rendah. Reputasi underwriter diyakini menjadi pertimbangan penting bagi investor untuk membeli saham suatu perusahaan. Oleh karena itu, bisa dijelakan Reputasi Underwriter (UND) berpengaruh negatif terhadap underpricing. Hal ini juga dijelaskan oleh peneliti sebelumnya, Irawati (2009) dengan judul Analisis Pengaruh Informasi Akuntansi Dan Non Akuntansi Terhadap Underpricing Pada 9 Perusahaan yang Melakukan Initial Public Offering di BEI. Hasil penelitiannya 
menunjukkan bahwa ariabel Size, ROI, EPS, finansial leverage, reputasi auditor, reputasi underwriter dan jenis industri berpengaruh signifikan negatif terhadap Underpricing. Andina (2011) mengenai Pengaruh Informasi Akuntansi dan Non Akuntansi terhadap Underpricing Saham menyimpulkan Reputasi underwriter berpengaruh signifikan positif terhadap underpricing saham perusahaan yang melakukan initial public offering pada tahun 2008-2011. Hipotesis yang dibentuk:

\section{H6 $_{6}$ : Reputasi Underwriter berpengaruh negatif terhadap Underpricing Saham pada Bursa Efek Indonesia yang melakukan IPO periode 2007-2013}

Reputasi Auditor (AUD) merupakan variabel dummy yang diukur dengan menggunakan skala 1 untuk auditor dan afiliasinya yang termasuk Big 4 Auditor Firm dan skala 0 untuk auditor dan afiliasinya yang tidak termasuk Big 4 Auditor Firm. Reputasi auditor berpengaruh pada kredibilitas laporan keuangan ketika suatu perusahaan go public. Auditoryang bereputasi tinggi dapat digunakan sebagai tanda atau petunjuk terhadap kualitas perusahaan emiten. Emiten yang memilih untuk menggunakan auditor yang berkualitas akan dinilai positif oleh investor yaitu emiten mempunyai informasi yang tidak menyesatkan mengenai prospeknya di masa mendatang. Oleh karena itu, bisa dijelakan Reputasi Auditor (AUD) berpengaruh negatif terhadap underpricing.

\section{$\mathrm{H}_{7}$ : Reputasi Auditor berpengaruh negatif terhadap Underpricing Perusahaan yang Melakukan IPO di Bursa Efek Indonesia Periode $2007-2013$}

Herding (HERD) merupakan variabel dummy yangdidefinisikan sebagai perilaku investor yang cenderung meniru atau mengikuti perilaku investor lain Herding diukur dengan menggunakan model CSSD (Cross-sectional Standar Deviation) dengan menghitung nilai standar deviasi. Skor 1 diberikan kepada perusahaan yang memperoleh nilai negatif pada perhitungan Z-Score, dan nilai 0 diberikan kepada perusahaan yang memperoleh nilai positif pada Z-score. Perilaku investor tersebut dapat membuat harga saham perdana mengalami fenomena underpricing. Oleh karena itu perilaku Herding berpengaruh positif terhadap underpricing. Hal ini juga dijelaskan oleh peneliti sebelumnya, Gleason 
JEMAP : Jurnal Ekonomi, Manajemen, Akuntansi dan Perpajakan

et al (2003) dalam penelitian yang berjudul Analysis of Intraday Herding Behavior Among the Sector ETFs. Sampel diperoleh dari database TAQ NYSE periode 1999 sampai 2002. Hasil penelitian adalah terdapat perilaku herding pada indeks NYSE.Bowe et al (2004) dalam penelitiannya yang berjudul Investor Herding during Financial Crisis: A Clinical Study of The Jakarta Stock Exchange. Sampel yang digunakan adalah seluruh perushaan yang terdaftar di JSX periode 1997 hingga 1999. Hasil penelitiannya adalah terdapat fenomena herding pada saat itu, terutama pada saat krisis yang menimpa Asia (Indoneia) pada tahun 1998-1999. Hipotesis yang diajukan berdasarkan penjelasan di atas adalah sebagai berikut:

\section{$\mathrm{H}_{8}$ : Fenomena herding berpengaruh positif terhadapUnderpricing Perusahaanyang Melakukan IPO di Bursa Efek Indonesia Periode} $2007-2013$

Kurs (KURS) diproxikan dengan merasiokan kurs Rupiah terhadap Dollar Amerika. Hubungan antara nilai tukar Rupiah dengan IHSG adalah berbanding lurus. Jika nilai tukar rupiah sedang meningkat, maka akan mempengaruhi bursa untuk mengalami rebound. Jika hal ini terjadi maka saham-saham yang terdaftar di bursa, termasuk saham yang sedang IPO pada hari tersebut juga mengalami peningkatan. Oleh karena itu, dapat dijelaskan bahwa nilai tukar Rupiah (Kurs) berhubungan siginifikan positif terhadap Underpricing. Hal ini juga dijelaskan oleh peneliti sebelumnya, Hardiningsih (2001) meneliti tentang Pengaruh Faktor Fundamental dan Risiko Ekonomi Terhadap Return Saham Pada Perusahaan di Bursa Efek Jakarta. Sampel yang digunakan adalah perusahaan yang melakukan IPO pada periode 2000 - 2002. Metode yang diguakan adalah uji parsial. Hasilnya adalah nilai tukar rupiah mempunyai pengaruh negatif terhadap Indeks Harga Saham Gabungan (IHSG). Yolanda (2005) meneliti tentang Variabel-variabel yang Mempengaruhi Fenomena Underpricing pada Penawaran Saham Perdana Di BEJ Tahun 1994 - 2001. Sampel yang digunakan adalah seluruh perusahaan yang melakukan penawaran saham perdana di BEJ dari tahun 1994 - 2001. Hasilnya adalah kurs berpengaruh signifikan negatif terhadap underpricing. Hipotesis dibentuk: 
JEMAP : Jurnal Ekonomi, Manajemen, Akuntansi dan Perpajakan

$\mathrm{H}_{9}$ : Nilai rata-rata kurs rupiah terhadap dollar Amerika Serikat berpengaruh negatif terhadap Underpricing Perusahaan yang Melakukan IPO di Bursa Efek Indonesia Periode 2007 - 2013

\section{METODE}

Populasi penelitian ini adalah seluruh perusahaan yang melakukan IPO di Bursa Efek Indonesia. Sampel yang digunakan dalam penelitian ini menggunakan seluruh perusahaan yang melakukan IPO di Bursa Efek Indonesia periode 2007 sampai dengan 2013. Data penelitian yang digunakan dalam penelitian ini adalah nama perusahaan yang melakukan IPO, harga penawaran saat IPO, data perdagangan sektoral, diperoleh dari situs www.idx.co.id, www.e-bursa.com, www.sahamok.com, www.yahoofinance.com.Variabel independen variabel yang mempengaruhi variabel dependen, baik secara positif maupun negatif. Variabel independen dari penelitian ini adalah sebagai berikut Current Assets (CR). Rasio ini menunjukan kemampuan perusahaan untuk membayar hutang yang harus segera dibayar yang dibayar menggunakan aset lancar pada periode tertentu. Total aset turn over (TATO). Rasio ini menunjukan kemampuan kecepatan perputaran total aset dalam periode tertentu. (Eugene et al, 1998). Return on Asset (ROA). Rasio ini menggambarkan kemampuan perusahaan untuk menggunakan seluruh aset yang dimiliki oleh perusahaan untuk menghasilkan laba. (Eugene et al, 1998). Debt to Equty Ratio (DER). Rasio ini menunjukkan perbandingan antara total hutang dengan total ekuitas perusahaan pada periode tertentu. (Eugene et al, 1998).

Rencana Penggunaan Dana (RPD) adalah variabel dummyyang diukur dengan memberikan skala 1 kepada perusahaan yang melakukan IPO dengan tujuan bahwa dana yang didapat pada saat IPO digunakan untuk investasi aset dan /atau ekspansi, jika prosentase tersebut lebih dari 50\%, sedangkan jika dana IPOnya digunakan untuk hal-hal lain selain investasi aset dan/atau ekspansi perusahaan, maka akan diberikan skala 0 persentase, pendekatan ini juga digunakan dalam penelitian Kim et al(1993) dalam Ismiyati et al (2010) 
JEMAP : Jurnal Ekonomi, Manajemen, Akuntansi dan Perpajakan

Reputasi Underwriter (UDW)adalah variabel dummy yang diukur melalui rangking underwriter masuk 10 besar berdasarkan frequency $(\mathrm{X})$ yang diperoleh pada fact book yang dikeluarkan oleh BEI setiap tahun. Reputasi Underwriter dikatakan baik jika underwriter tersebut aktif dalam melakukan jual beli saham. Skala 1 jika underwriter tersebut masuk dalam jajaran 10 besar underwriter teraktif, dan skala 0 jika underwriter berada diluar jajaran 10 besar underwriter teraktif. Pendekatan ini diperoleh berdasarkan penelitian yang dilakukan oleh Yasa (2013).

Reputasi Auditor (AUD) merupakan variabel dummy yang diukur dengan menggunakan skala 1 untuk auditor dan afiliasinya yang termasuk Big 4 Auditor Firm dan skala 0 untuk auditor dan afiliasinya yang tidak termasuk Big 4 Auditor Firm. Keempat KAP besar tersebut adalah Deloite dan afiliasinya, PwC dan afiliasinya, Ernst \& Young dan afiliasinya, KPMG dan afiliasinya. Peringkat juga digunakan dalam penelitian Kristiantari (2013). Pendekatan ini juga digunakan oleh Yasa (2001).

Herding (HERD) merupakan variabel dummy yangdidefinisikan sebagai perilaku investor yang cenderung meniru atau mengikuti perilaku investor lain (Ismiyati et al, 2010). Herding diukur dengan menggunakan model CSSD (Crosssectional Standar Deviation) yang dikembangkan oleh Christine and Huang (1995) dalam Caparrelll et al (2004) dengan menghitung nilai standar deviasi.

\section{$\operatorname{CSSD}_{\mathrm{t}}=$}

Keterangan:

$\mathrm{CSSD}_{\mathrm{t}}=$ Cross-sectional Standar Deviation pada $\mathrm{t}$

$\mathrm{R}_{\mathrm{i}, \mathrm{t}} \quad=$ Return Saham pada saat IPO

$\mathrm{R}_{\mathrm{m}, \mathrm{t}}=$ Return Market (Sektor) pada saat perusahaan melakukan IPO

$\mathrm{N}=$ Jumlah keseluruhan perusahaan dalam suatu sektor

Model analisis yang dipergunakan dalam penelitian ini adalah analisis regresi linier berganda, dengan persamaan sebagai berikut: 


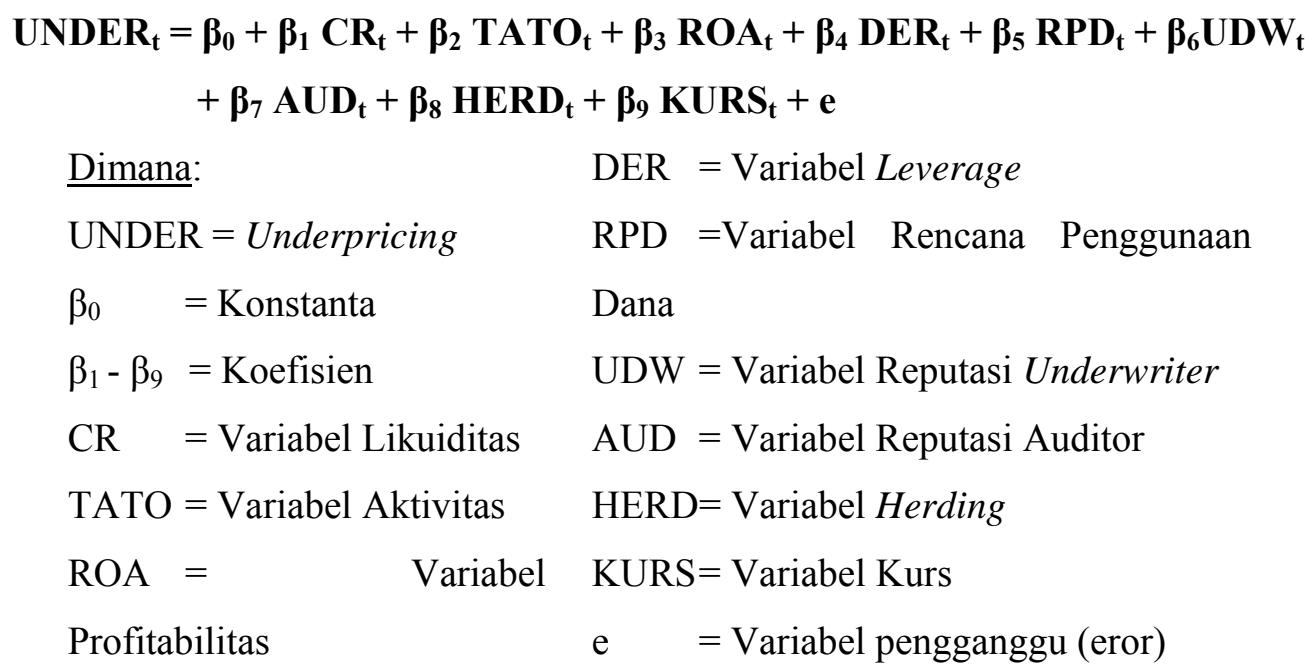

\section{HASIL}

Statistik deskriptif merupakan statistik yang mengambarkan mengenai karakteristik dari masing-masing variabel penelitian sehingga dapat diperoleh gambaran secara umum tentang kondisi perusahaan yang diteliti. Dalam penelitian ini diperoleh data sebanyak 86 observasi tahun 2007-2013.Terdapat satu sampel yang dibuang, yaitu PT Sarana Central Bajatama (BAJA) yang melakukan IPO pada tanggal 21 Desember 2012, dikarenakan memiliki nilai ekuitas negatif. Hal ini mengakibatkan outlier pada sampel terlalu tinggi. Hasil uji normalitas dari data awal 85 observasi memiliki distribusi tidak normal karena nilai signifikansi Kolmogrof-Smirnov $<0,05$. Untuk menormalkan data tersebut maka dihapus data ekstrim yang tidak berdistribusi normal sehingga didapat 52 observasi. Berdasarkan hasil penelitian ini, variabel UNDER (underpricing) memiliki nilai rata-rata 0,2246 dan standar deviasinya sebesar 0,21121. Artinya bahwa rata-rata rasio underpricing yang didapat dari selisih closing price dengan offering price dibagi dengan offering pricesebesar 22,46\%. Variabel CR (current assets nilai rata-rata current assets adalah 1,3298 dan standar deviasinya sebesar0,95494. Artinya bahwa rata-rata kemampuan untuk membayar utang yang segera harus dipenuhi dengan aset lancarsebesar95,494\%.

Variabel TATO (total aset turn over) nilai rata-rata total aset turn over adalah 0,5054 dan standar deviasinya sebesar0,48498. Artinya bahwa rata-rata 
JEMAP : Jurnal Ekonomi, Manajemen, Akuntansi dan Perpajakan

kemampuan dana yang tertanam dalam keseluruhan aset berputar dalam suatu periode tertentu atau kemampuan modal yang diinvestasikan untuk menghasilkan revenue sebesar 48,498\%.Variabel ROA (return on asset) nilai rata-rata return on asset adalah 0,0793dan standar deviasinya sebesar 0,15388. Artinya bahwa rata-rata kemampuan perusahaan untuk menghasilkan laba dengan menggunakan asset yang dimiliki sebesar $15,388 \%$.Variabel DER (debt to equty ratio) nilai rata-rata debt to equty ratio adalah 2,6843dan standar deviasinya sebesar2,15833. Artinya bahwa rata-rata persentase penyediaan dana oleh pemegang saham terhadap pemberi pinjaman sebesar 215,833\%.

Variabel KURS (kurs) nilai rata-rata kurs adalah 0,0009 dan standar deviasinya sebesar0,00403. Artinya bahwa rata-rata nilai penutupan kurs tengah Bank Indonesia Rupiah terhadap Dollar Amerika pada saat perusahaan melakukan IPO sebesar $0,00403 \%$. Rencana penggunaan dana (RPD) dalam penelitian ini diukur dengan variabel dummy, di mana skala 1 untuk perusahaan yang melakukan IPO dengan tujuan investasi asset dan pengembangan pada perusahaan serta persentase penggunaan dana IPO lebih dari 50\%, sedangkan skala 0 untuk perusahaan yang memiliki tujuan IPO lainnya serta persentase penggunaan dana IPO kurang dari 50\%. Berdasarkan hasil penelitian ini dari 52 perusahaan sampel terdapat 14 perusahaan yang memiliki tujuan IPO lainnya serta persentase penggunaan dana IPO kurang dari 50\% dan 38 perusahaan yang melakukan IPO dengan tujuan investasi asset dan pengembangan pada perusahaan serta persentase penggunaan dana IPO lebih dari 50\%.

Reputasi underwriter (UDW)dalam penelitian ini diukur dengan variabel dummy, yang diukur melalui rangking underwriter masuk 10 besar berdasarkan frequency $(\mathrm{X})$ yang diperoleh pada fact book yang dikeluarkan oleh BEI setiap tahun. Reputasi Underwriter dikatakan baik jika underwriter tersebut aktif dalam melakukan jual beli saham. Skala 1 jika underwriter tersebut masuk dalam jajaran 10 besar underwriter teraktif, dan skala 0 jika underwriter berada diluar jajaran 10 besar underwriter teraktif. Berdasarkan hasil penelitian ini dari 52 perusahaan sampel terdapat 33 perusahaan dengan underwriter yang tidak termasuk 10 besar 
JEMAP : Jurnal Ekonomi, Manajemen, Akuntansi dan Perpajakan

berarti tidak memiliki reputasi dan 19 perusahaan dengan underwriter termasuk dalam 10 besar berarti memiliki reputasi tinggi.

Reputasi auditor(AUD) dalam penelitian ini diukur dengan variabel dummy, di mana skala 1 untuk auditor dan afiliasinya yang termasuk dalam kategori empat besar dan 0 untuk auditor yang tidak termasuk dalam kategori empat besar. Keempat KAP besar tersebut adalah Deloite dan afiliasinya, PwC dan afiliasinya, Ernst \& Young dan afiliasinya, KPMG dan afiliasinya. Berdasarkan hasil penelitian ini dari 52 perusahaan sampel terdapat 32 perusahaan yang tidak termasuk dalam kategori empat besar dan 20 perusahaan yang termasuk dalam kategori empat besar.Variabel herding merupakan variabel dummy yangdidefinisikan sebagai perilaku investor yang cenderung meniru atau mengikuti perilaku investor lain. Herding diukur dengan menggunakan model CSSD. Berdasarkan hasil penelitian ini dari 52 perusahaan sampel terdapat 6 perusahaan yang tidak mengalami fenomena herding dan 46 perusahaan yang mengalami fenomena herding.

\section{PENGUJIAN HIPOTESIS}

Tujuan dari uji normalitas adalah untuk mengetahui apakah model regresi antara variabel dependen dan variabel independen memiliki distribusi normal ataukah tidak. Data penelitian ini telah menghilangkan 34 data penelitian yang ekstrim dari 85 menjadi 52 nilai signifikansi akhir Kolmogrof-Smirnov sebesar 0,200. Nilai signifikansi tersebut lebih besar dari 0,05 sehingga dapat disimpulkan data penelitian telah terdistribusi secara normal.Serta semua uji autokorelasi, multikolinieritas, heteroskedastisitas, telah lolos. Maka model regresi dapat digunakan untuk menguji hipotesis.

Pengujian hipotesis dilakukan dengan uji regresi linier berganda untuk mengetahui pengaruh faktor finansial dan non-finansial terhadap underpricing pada perusahaan yang melakukan IPO di BEI periode 2007-2013. Berikut ini adalah hasil uji hipotesis.Uji F digunakan untuk mengetahui apakah model regresi tepat dalam memprediksi variabel dependen, di mana ketepatan tersebut 
JEMAP : Jurnal Ekonomi, Manajemen, Akuntansi dan Perpajakan

ditunjukkan oleh tingkat signifikansi yang nilainya lebih kecil dari 0,05. Berdasarkan Tabel 2, di atas dapat dilihat bahwa F memiliki koefisien 9,414 dan signifikansi sebesar 0,000 lebih besar dari 0,05 artinya setiap variabel independen dapat menerangkan variabel dependen. Model regresi dapat digunakan untuk memprediksi UNDERP (underpricing) atau model regresi dapat digunakan untuk melakukan pengujian yang dibutuhkan dan hasilnya mampu menjelaskan hal-hal yang sedang diteliti.Koefisien determinasi (adjusted $\mathrm{R}^{2}$ ) dimaksudkan untuk mengetahui tingkat ketepatan yang paling baik dalam analisis regresi, di mana hal ini ditunjukkan oleh besarnya adjusted $\mathrm{R}^{2}$ antara 0 dan 1 . Apabila nilai adjusted $\mathrm{R}^{2}$ semakin mendekati satu maka presentase perubahan variabel dependen yang disebabkan oleh variabel independen semakin besar. Berdasarkan Tabel 4.10. di atas dapat dilihat bahwa nilai adjusted $\mathrm{R}^{2} 0,643$ berarti daya penjelas variabel independen terhadap variabel dependen adalah sebesar $64,3 \%$ sedangkan sisanya $42,9 \%$ dijelaskan oleh faktor lain di luar model.

Hasil regresi menunjukkan adanya pengaruh antara masing-masing variabel independen terhadap Underpricing, yaitu:Rasio likuiditas berpengaruh negatif terhadap Underpricing pada Perusahaan yang Melakukan IPO di Bursa Efek Indonesia Periode 2007-2013. Hasilnyavariabel rasio likuiditas(CR)memiliki tingkat signifikan sebesar 0,093 lebih kecil dari0,1 menunjukkan secara statistik signifikan dan koefisien regresi sebesar -1,720. Hal ini berarti bahwa rasio likuiditasberpengaruh negatifterhadap underpricing pada perusahaan yang melakukan IPO di BEI. Dengan demikian, $\mathbf{H}_{\mathbf{1}}$ dalam penelitian iniditerima.Hasil ini sesuai dengan bukti empiris sebelumnya yang dilakukan Paramitha (2007) dan Yuliana (2013) membuktikan bahwa rasio likuiditas berpengaruh terhadap underpricing saham pada BEI yang melakukan IPO. Tingkat likuiditas perusahaan yang diproxikan dengan Current Ratio (CR) memberikan bahan pertimbangan bagi para investor dan calon investor dalam mengambil keputusan, apakah akan melakukan pembelian saham perusahaan dengan mempertimbangkan kinerja perusahaaan yang bersangkutan. 
JEMAP : Jurnal Ekonomi, Manajemen, Akuntansi dan Perpajakan

Rasio aktivitas berpengaruh negatif terhadap Underpricing pada Perusahaan yang Melakukan IPO di Bursa Efek Indonesia Periode 20072013. Hasil penelitian ini memperlihatkan rasio aktivitas yang diproxikan dengan TATO(Total Asset Turnover)memiliki tingkat signifikan sebesar 0,563 jauh di atas 0,05. Hal ini berarti bahwa rasio aktivitastidak berpengaruh terhadap underpricing saham pada perusahaan yang melakukan IPO di BEI. Dengan demikian, $\mathbf{H}_{2}$ dalam penelitian iniditolak.Hasil ini sesuai dengan bukti empiris sebelumnya yang dilakukan oleh Dewi (2007) dan Sansuri (2008) membuktikan bahwa rasio aktivitastidak berpengaruh terhadap underpricing saham pada BEI yang melakukan IPO. Tingkat aktivitas perusahaan yang diproxikan dengan Total Asset Turnover (TATO) tidak memberikan bahan pertimbangan bagi para investor dan calon investor dalam mengambil keputusan, apakah akan melakukan pembelian saham perusahaan dengan mempertimbangkan kinerja perusahaaan yang bersangkutan.Hasil statistik diatas membuktikan bahwa aktivitas perusahaan tidak mempunyai hubungan terhadap tingkat underpricing sehingga investor dalam pengambilan keputusan tidak melihat tingkat aktivitas perusahaan. Walaupun perusahaan yang melakukan IPO memiliki tingkat aktivitas yang baik, namun bisa dilihat secara statistik bahwa investor tidak melihat hal itu untuk pengambilan keputusannya. Tingkat aktivitas perusahaan dimana dalam penelitian ini diproxikan dengan Total Asset Turnover (TOTA). Rasio TOTA menunjukan kemampuan kecepatan perputaran total aset dalam periode tertentu. Investor hanya mempertimbangkan tingkat likuiditas dan profitabilitas perusahaan yang melakukan IPO sebagai acuan dalam pengambilan keputusan. Investor menganggap perusahaan yang IPO cukup likuid dan profit saja, walaupun tingkat aktivitasnya tinggi.

Rasio profitabilitas berpengaruh negatif terhadap Underpricing pada Perusahaan yang Melakukan IPO di Bursa Efek Indonesia Periode 20072013. Hasil penelitian ini memperlihatkan variabel rasio profitabilitas (ROA) memiliki tingkat signifikan sebesar 0,080 lebih kecil dari0,1 menunjukkan secara statistik signifikan dan koefisien regresi sebesar -1,793. Hal ini berarti bahwa rasio likuiditasberpengaruh negatifterhadap underpricing pada perusahaan yang 
JEMAP : Jurnal Ekonomi, Manajemen, Akuntansi dan Perpajakan

melakukan IPO di BEI. Dengan demikian, $\mathbf{H}_{3}$ dalam penelitian iniditerima.Hasil ini sesuai dengan bukti empiris sebelumnya yang dilakukan oleh Hardiningsih (2011) membuktikan bahwa rasio profitabilitas berpengaruh terhadap underpricing saham pada BEI yang melakukan IPO. Tingkat profitabilitas perusahaan yang diproxikan dengan Return On Assest (ROA) memberikan bahan pertimbangan bagi para investor dan calon investor dalam mengambil keputusan, apakah akan melakukan pembelian saham perusahaan dengan mempertimbangkan kinerja perusahaaan yang bersangkutan. Tingkat profitabilitas perusahaan dapat menjadi bahan pertimbangan bagi para investor dan calon investor dalam mengambil keputusan ketika akan melakukan pembelian saham perusahaan dengan mempertimbangkan kinerja perusahaan yang bersangkutan. Hasil statistik diatas juga membuktikan penelitian terdahulu bahwa jika profitabilitas perusahaan mempunyai hubungan terhadap tingkat underpricing. Investor akan melihat profitabilitas perusahaan dalam pengambilan keputusan. Jika tingkat profitabilitas perusahaan baik, maka perusahaan dinilai akan memiliki kemampuan untuk menghasilkan laba dikemudian hari sehingga bisa memberikan keuntungan kepada investor dalam bentuk deviden.

Rasio leverage berpengaruh negatif terhadap Underpricing pada Perusahaan yang Melakukan IPO di Bursa Efek Indonesia Periode 20072013. Hasil penelitian ini memperlihatkan variabel rasio leverage(DER)memiliki tingkat signifikan sebesar 0,49 lebih kecil dari0,05 menunjukkan secara statistik signifikan dan koefisien regresi sebesar 2,031. Hal ini berarti bahwa rasio leverage berpengaruh positif terhadap underpricing pada perusahaan yang melakukan IPO di BEI. Dengan demikian, $\mathbf{H}_{4}$ dalam penelitian iniditerima.Hasil ini sesuai dengan bukti empiris sebelumnya yang dilakukan oleh Aini (2013) membuktikan bahwa rasio leverege berpengaruh terhadap underpricing saham pada BEI yang melakukan IPO. Tingkat leverege perusahaan yang diproxikan dengan Debt to Equity (DER) memberikan bahan pertimbangan bagi para investor dan calon investor dalam mengambil keputusan, apakah akan melakukan pembelian saham perusahaan dengan mempertimbangkan kinerja perusahaaan yang bersangkutan. Tingkat leverege perusahaan dapat menjadi bahan 
JEMAP : Jurnal Ekonomi, Manajemen, Akuntansi dan Perpajakan

pertimbangan bagi para investor dan calon investor dalam mengambil keputusan ketika akan melakukan pembelian saham perusahaan dengan mempertimbangkan kinerja perusahaan yang bersangkutan. Hasil statistik diatas juga membuktikan penelitian terdahulu bahwa jika likuiditas perusahaan mempunyai hubungan terhadap tingkat underpricing. Investor akan melihat leverege perusahaan dalam pengambilan keputusan. Jika tingkat leverege perusahaan baik, maka perusahaan dinilai tidak mampu untuk membayar hutang-hutang jangka pendek.

Rencana Penggunaan Dana (RPD) IPO berpengaruh negatif terhadap Underpricing pada Perusahaan yang Melakukan IPO di Bursa Efek Indonesia periode 2007 - 2013. Hasil penelitian ini memperlihatkan variabel rencana penggunaan dana (RPD) memiliki tingkat signifikan sebesar 0,000 lebih kecil dari0,05 menunjukkan secara statistik signifikan dan koefisien regresi sebesar -4,517. Hal ini berarti bahwa Rencana Penggunaan Dana IPOberpengaruh negatifterhadap underpricing pada perusahaan yang melakukan IPO di BEI. Dengan demikian, $\mathbf{H}_{5}$ dalam penelitian iniditerima.Hasil ini sesuai dengan bukti empiris sebelumnya yang yang dilakukan Kristianti(2012) membuktikan bahwa rencana penggunaan dana berpengaruh terhadap underpricing saham pada BEI yang melakukan IPO penelitian. Rencana Penggunaan Dana IPO memberikan bahan pertimbangan bagi para investor dan calon investor dalam mengambil keputusan, apakah akan melakukan pembelian saham perusahaan dengan mempertimbangkan kinerja perusahaaan yang bersangkutan.Investor dalam pengambilan keputusan akan menilai dana yang didapat perusahaan digunakan untuk melakukan investasi (pembelian aset dsb) atau digunakan selain keperluan investasi, misalnya untuk pembayaran hutang-hutang perusahaan. Jika perusahaan menggunakan dana IPO untuk keperluan investasi, investor melakukan penilaian baik terhadap perusahaan tersebut. Berdasarkan data statistik juga dibuktikan bahwa rencana penggunaan dana IPO memiliki hubungan terhadap tingkat underpricing.

Reputasi Underwriter berpengaruh negatif terhadap Underpricing pada pada Perusahaan yang Melakukan IPO di periode 2007 - 2013. Hasil 
penelitian ini memperlihatkan variabel reputasi underwriter (UDW) memiliki tingkat signifikan sebesar 0,000 lebih kecil dari 0,05 menunjukkan secara statistik signifikan dan koefisien regresi sebesar $-4,789$. Hal ini berarti bahwa reputasi underwriter berpengaruh negatif terhadap underpricing saham pada BEI yang melakukan IPO. Dengan demikian, $\mathbf{H}_{6}$ dalam penelitian ini diterima.Hasil ini sesuai dengan bukti empiris sebelumnya yang dilakukan Aini (2013) membuktikan bahwa reputasi underwriter berpengaruh negatif terhadap underpricing saham pada BEI yang melakukan IPO. Reputasi underwriter memberikan bahan pertimbangan bagi para investor dan calon investor dalam mengambil keputusan, apakah akan melakukan pembelian saham perusahaan dengan mempertimbangkan kinerja perusahaaan yang bersangkutan. Reputasi underwriter yang digunakan oleh perusahaan juga mempengaruhi pengambilan keputusan investor. Terlihat juga dari data statistik bahwa nilai signifikan 0,000 jauh dibawah 0,05 artinya bahwa reputasi underwriter sangat berpengaruh terhadap underpricing, dimana reputasi underwriter tersebut digunakan investor untuk pengambilan keputusan. Semakin baik reputasi underwriter yang digunakan oleh perusahaan, maka investor akan lebih mempercayai kinerja dari underwriter tersebut. Diharapkan tidak terjadi underpricing terhadap perusahaan yang melakukan IPO.

\section{Reputasi Auditor berpengaruh negatif terhadap Underpricing pada} Perusahaan yang Melakukan IPO di periode 2007 - 2013. Berdasarkan tabel 2. Diatas, variabel reputasi auditor (AUD) memiliki tingkat signifikan sebesar 0,000 lebih kecil dari 0,05 menunjukkan secara statistik signifikan dan koefisien regresi sebesar -5,206. Hal ini berarti bahwa reputasi auditor berpengaruh negatif terhadap underpricing saham pada BEI yang melakukan IPO. Maka, $\mathbf{H}_{7}$ dalam penelitian ini diterima.Hasil ini sesuai dengan bukti empiris sebelumnya yang dilakukan Kristiantari (2013) membuktikan bahwa reputasi auditor berpengaruh negatif terhadap underpricing saham pada BEI yang melakukan IPO. Reputasi auditor memberikan bahan pertimbangan bagi para investor dan calon investor dalam mengambil keputusan, apakah akan melakukan pembelian saham perusahaan dengan mempertimbangkan kinerja perusahaaan yang 
JEMAP : Jurnal Ekonomi, Manajemen, Akuntansi dan Perpajakan

bersangkutan.Reputasi auditor yang digunakan oleh perusahaan juga mempengaruhi pengambilan keputusan investor. Terlihat juga dari data statistik bahwa nilai signifikan 0,000 jauh dibawah 0,05 artinya bahwa reputasi auditor sangat berpengaruh terhadap underpricing, dimana reputasi auditor tersebut digunakan investor untuk pengambilan keputusan. Semakin baik reputasi auditor yang digunakan oleh perusahaan, maka investor akan lebih mempercayai kinerja dari tersebut. Diharapkan tidak terjadi underpricing terhadap perusahaan yang melakukan IPO.

Fenomena herding berpengaruh positifterhadap Underpricing pada Perusahaan yang Melakukan IPO di periode 2007 - 2013. Hasil penelitian ini memperlihatkan variabel herding (HERD) memiliki tingkat signifikan sebesar 0,027 lebih kecil dari 0,05 menunjukkan secara statistik signifikan dan koefisien regresi sebesar 2,294. Hal ini berarti bahwa herding berpengaruh positif terhadap underpricing saham pada BEI yang melakukan IPO. Maka, $\mathbf{H}_{\mathbf{8}}$ dalam penelitian ini diterima.Hasil ini sesuai dengan bukti empiris sebelumnya yang membuktikan bahwa fenomena herding berpengaruh positif terhadap underpricing pada BEI. Bowe et al (2004) yang menyebutkan bahwa fenomena herding terjadi pada saat krisis mobeter terjadi di Indonesia pada tahun 1998-1999. Berdasarkan data statistik dan penelitian terdahulu, dibuktikan bahwa fenomena herding terjadi di Indonesia. Perilaku investor dalam pengambilan keputusan selain mempertimbangan aspek fundamental perusahaan, tetapi juga mengkuti investor lain sehingga perilaku herding terjadi di Indonesia.

Nilai rata-rata kurs rupiah terhadap dollar Amerika Serikat berpengaruh negatif terhadap Underpricing pada Perusahaan yang Melakukan IPO di BEI periode 2007 - 2013. Hasil penelitian ini memperlihatkan variabel kurs (KURS) memiliki tingkat signifikan sebesar 0,000 lebih kecil dari 0,05 menunjukkan secara statistik signifikan dan koefisien regresi sebesar -5,017. Hal ini berarti bahwa kurs berpengaruh negatif terhadap underpricing saham pada BEI yang melakukan IPO. Dengan demikian, H9 dalam penelitian ini diterima.Hasil ini sesuai dengan bukti empiris sebelumnya yang 
JEMAP : Jurnal Ekonomi, Manajemen, Akuntansi dan Perpajakan

membuktikan bahwa kurs berpengaruh negatif terhadap underpricing saham pada BEI yang melakukan IPO, seperti Hardiningsih et al (2002). Nilai rata-rata kurs saat IPO memberikan bahan pertimbangan bagi para investor dan calon investor dalam mengambil keputusan, apakah akan melakukan pembelian saham perusahaan dengan mempertimbangkan kinerja pasar uang pada saat perusahaan melakukan IPO.Kurs yang digunakan oleh perusahaan juga mempengaruhi pengambilan keputusan investor. Terlihat juga dari data statistik bahwa nilai signifikan 0,000 jauh dibawah 0,05 artinya bahwa kurs sangat berpengaruh terhadap underpricing, dimana kurs tersebut digunakan investor untuk pengambilan keputusan. Semakin baik kinerja pasar uang pada saat perusahaan melakukan IPO, maka investor akan lebih tertarik untuk melakukan pembelian saham.

\section{SIMPULAN DAN SARAN}

Berdasarkan hasil pengujian yang diperoleh, maka kesimpulan yang dapat diambil adalah Rasio likuiditas (CR), Rasio profitabilitas (ROA), Rencana Penggunaan Dana, Reputasi Auditor, Fenomena herding, Nilai rata-rata kurs rupiah terhadap dollar Amerika Serikat berpengaruh negatifterhadap Underpricing pada perusahaan yang melakukan penawaran saham perdana di Bursa Efek Indonesia. Rasio leverage (DER) berpengaruh positif terhadap Underpricingpada perusahaan yang melakukan penawaran saham perdana di Bursa Efek Indonesia. Sedangkan, Rasio aktivitas (TOTA) tidak berpengaruh terhadap Underpricingpada perusahaan yang melakukan penawaran saham perdana di Bursa Efek Indonesia.

Keterbatasan dalam penelitian ini adalah Variabel herding belum mampu membuktikan secara langsung perilaku herding di Bursa Efek Indonesia dikarenakan investor institusional lebih berpengaruh terhadap perusahaan yang melakukan penawaram perdana daripada investor individual. Investor konstitusional adalah korporasi yang melakukan kegiatan investasi, sehingga penelitian ini tidak berhasil membuktikan perilaku herding di pasar modal Indonesia. Perilaku herding adalah perilaku investor meniru investor lain tanpa 
JEMAP : Jurnal Ekonomi, Manajemen, Akuntansi dan Perpajakan

ISSN : $\quad$ | Vol. 1 | No. 1 | April 2018

mempertimbangkan aspek fundamental perusahaan. Keterbatasan dalam penelitian ini adalah sebagai berikut: Penelitian berikutnya, variabel herding lebih melihat pada perilaku investor individual saja dikarenaka perilaku herding meneliti tentang perilaku investor meniru investor lain tanpa mempertimbangkan aspek fundamental perusahaan. Investor yang dimaksut adalah investor individual. Kedua, penelitian-penelitian berikutnya dapat menggunakan variabel-variabel lain, terutama untuk variabel non-finansial, seperti umur perusahaan, prosentase yang dimiliki oleh pemilik.

\section{DAFTAR PUSTAKA}

Bowe, Michael., Daniela, D. 2003. Investor herding during financial crisis: A clinical study of the Jakarta Stock Exchange. Pacific-Basin FinanceJournal 12 (2004) 387-418

Brigham, Eugene F, Joel F Houtston. 2000. "Fundamentas of Financial Management. USA

Caparrelll. Franco, Anna Maria D'Arcangells, Alexander Cassuto. Journal of Behaviour Finance.'Herding in the Italuan Stock Market: A Case of Behavioural Finance" 2004. New York University

Ghozali, Imam. 2001. Aplikasi Analisis Multivariate dengan Program SPSS. Semarang: Badan Penerbit Universitas Diponegoro.

Gleason. Kimberly C., Ike Mathur., Mark A. Paterson. 2003. "Analysis of Intraday Herding Behavior Among th Sector ETFs".

Habib, Michael A., Alexander P. Ljungqvist. "Underpricing and Entrepreneurial Wealth Losses in IPOs: Theory and Evidence. 2000: Journal of Economic Literature Classification.

Hardiningsih. 2002. Pancawati dan L. Suryanto. "Pengaruh Faktor Fundamental dan Risiko Ekonomi Terhadap Return Saham Pada Perusahaan di Bursa Efek Jakarta" Jurnal Strategi Bisnis, Vol. 8, Desember 2001, Tahun. VI, 2002.

Ismiyanti. Fitri dan Armansyah. Rohmad Fuad. 2010. Motif Go Public, Herding, Ukuran Perusahaan, dan Underpricing: Jurnal Manajemen Teori dan Terapan 3, No.1, April 2010. Universitas Airlangga.

Kim, Jeong Bong, I. Krisky dan J. Lee. 1993. "Motives for Going Public and Underpricing: New Findings from Korea". Journal of Business Financial and Accounting.

Kristiantari, I Dewa Ayu. 2012. "Faktor-Faktor yang Mempengaruhi Underpricing Saham pada Penawaran Saham Perdana Di Bursa Efek Indonesia" (Tesis). Denpasar: Universitas Udayana 
Kewal, Suramaya Suci. 2012. "Pengaruh Inflasi, Suku Bunga, Kurs, dan Pertumbuhan PDB terhadap Indeks Harga Saham Gabungan". Jurnal Economia Volume 8 pp 53-64. Palembang: Sekolah Tinggi Ilmu Ekonomi Musi.

Paramitha, Karina. 2007. “Analisis Kinerja Keuanga Perusahaan Publik Melalui Pengamatan Terhadap Pertumbuhan Harga dan Return Saham di Bursa Efek (Skripsi). Semarang: Universitas Katolik Soegijapranata.

Puspita, Tifani. 2010. “Analisis Faktor-faktor yang Mempengaruhi TingkatUnderpricing Saham pada Saar Initial Public Offering (IPO) di Bursa Efek Indonesia Periode 2005-2009 (Skirpsi). Semarang: UniversitasDiponegoro.

Rosyati dan Arifin Sebeni, 2002, “Analisis Faktor-Faktor yang MempengaruhiUnderpricing Saham pada Perusahaan Go Publik di Bursa Efek Jakarta (Tahun 1997 - 2000)", “Kumpulan Makalah Simposium Nasional Akuntansi V”, $\quad 286-297$.

Reese, J., William A. 1998. IPO Underpricing, Trading Volume and Investor Interest. Available from: URL: http://www.ssrn.com.

Sansuri, Yonathan. 2008. "Pengaruh Faktor Likuiditas. Leverge dan Dividen Terhadap Initial Return pada Perusahaan Manufaktur di Bursa Efek Jakarta Periode tahun 2004-2006" (Skipsi). Semarang. Universitas Katolik Soegijapranata.

Sun, Chuanli., Lewis D. Johnson. "The Role of Information Underpricing: Implication from Refiling Behaviour in the IPO Pricing Process. 2005: Queen's University.

Sisharini, Nanik. 2003. "Faktor-faktor yang Mempengaruhi Tingkat Harga Saham Perusahaan suransi yang Go Public di Bursa Efek Jakarta". Jurnal Penelitian Ilmu-Ilmu Sosial, Volume. XV, Nomor 2, tahun 2003, hal. 596609.

Yolana, Chastina dan Martani, Dwi. 2005. Variabel-Variabel yang Mempengaruhi Fenomena Underpricing pada Penawaran Saham Perdana di BEJ Tahun 1994-2001. Makalah Seminar, Seminar Nasional Akuntansi VIII. Solo.

Wang, Kung. 2005. "Auditor and Underriter Industry Specialization/ Differentation: Evidence from IPO Underpricing and Long- Term Performance (Dissertation). Texas. Texas A\&M University.

Wirawan Yasa, Gerianta. 2001. "Penyebab Underpricing Pada Penawaran Saham Perdana Di Bursa Efek Jakarta". h. 1-29.

Wirawan Yasa, Gerianta. 2013. 'Tingkat Underpricing dan Reputasi Underwriter”. E-Jurnal Akuntansi Universitas Undayana 4.1 (2013). H. 159-176. 